\title{
LARRAINIA, A NEW GENUS OF AMBLYSTEGIACEAE FROM THE CAPE HORN REGION OF CHILE
}

\author{
LARRAINIA (AMBLYSTEGIACEAE), НОВЫЙ РОД ИЗ РАЙОНА МЫСА ГОРН В ЧИЛИ \\ WILLIAM R. BUCK ${ }^{1} \&$ BERNARD GOFFINET ${ }^{2}$ \\ ВИЛЬЯМ Р. БАК ${ }^{1}$, БЕРНАР ГОФФИНЕ ${ }^{2}$
}

\begin{abstract}
Larrainia prorulosa W.R.Buck is described as a new genus and species of Amblystegiaceae from southernmost Chile. The new genus is characterized by a very small stature, differentiated branch and stem leaves, and short prorulose laminal cells. The two known collections are both sterile. Based on DNA sequence data, Larrainia is placed in the Amblystegiaceae, most closely related to Vittia. However, it is most similar morphologically to Conardia. The new species would probably have previously been placed in Rhynchostegiella in the Brachytheciaceae (as has been Conardia). The diversity within Rhynchostegiella is discussed.
\end{abstract}

Резюме

Описан новый род и вид из семейства Amblystegiaceae Larrainia prorulosa W.R.Buck с крайнего юга Чили. Для нового рода характерны очень мелкие размеры растений, дифференцированные стеблевые и веточные листья и короткие клетки пластинки листа с выступающими верхними углами. Оба известных образца вида стерильны. Larrainia отнесена к семейству Amblystegiaceae на основании данных последовательностей ДНК. По данным молекулярных маркеров наиболее близким к ней родом является Vittia, однако морфологически Larrainia больше похожа на Conardia. Новый вид сначала был предположительно отнесен к роду Rhynchostegiella из Brachytheciaceae (так же как и Conardia). Обсуждается морфологическое разнообразие рода Rhynchostegiella.

KEYWORDS: Amblystegiaceae, Brachytheciaceae, Chile, Conardia, Eurhynchiella, Larrainia, Rhynchostegiella, Vittia.

\section{INTRODUCTION}

Although short on land, southernmost South America is very rich in bryophytes. Occupying less than $0.01 \%$ of the Earth's land mass, the area harbors over $5 \%$ of the world's bryophytes (Rozzi et al., 2008). Even though the region is a hot spot for bryophyte diversity, it is somewhat surprising that a significant number of taxa are being found in it new to science. Certainly this is partly due to historical factors. In the early days of sailing ship expeditions, most ships either went north of the region, through the Straits of Magellan, or south of the region, nearer Antarctica, to avoid the treacherous seas with numerous rocky shoals. Of course there are exceptions, the most famous of which was the Erebus and Terror Expedition (Hooker, 1844-1860). One might predict that the bryoflora of the region would be a synthesis of that of further north in Tierra del Fuego, and further south in Antarctica. However, fieldwork was needed to prove such a hypothesis. In conjunction with John Engel and Matt von Konrat at the Field Museum, a grant was awarded to the senior author from the U.S. National Science Foundation to intensively collect in the region and to prepare a bryoflora.
The investigated flora region is defined as the political boundaries of the Provincia Antártica Chilena (excluding continental Antarctica). The project is funded for four years, with a trip each year to a quadrant of the region. One might assume that the region is fairly uniform geologically and climatically, but such is not the case. The westernmost part of the region receives about $4 \mathrm{~m}$ of precipitation per year but at the eastern end of the region only about 700 mm of rain falls per year (Rozzi et al., 2004). During the 2013 field season, the primary focus was on the area around Isla Navarino, i.e., the driest part of the flora region. During this time the only outcrops of calcareous substrates known locally were encountered. Previous fieldwork in the Cape Horn Archipelago has resulted in the discovery and description of several new species of mosses (Garilleti et al., 2012; Andreas, 2013). These previous publications as well as the current one are ample evidence of the bryological diversity of the Cape Horn Archipelago.

\section{MATERIALS AND METHODS}

DNA was extracted from a few branches of the holotype collection (Buck 60369, NY) using the NucleoSpin ${ }^{\circledR}$ plant kit from Macherey Nagel (Düren, Germany) fol-

1 - Institute of Systematic Botany, The New York Botanical Garden, Bronx, NY 10458-5126, U.S.A; e-mail: editorbuck@nybg.org

2 - Ecology and Evolutionary Biology, 75 North Eagleville Road, University of Connecticut, Storrs, CT 06269-3043, U.S.A; e-mail: bernard.goffinet@uconn.edu 


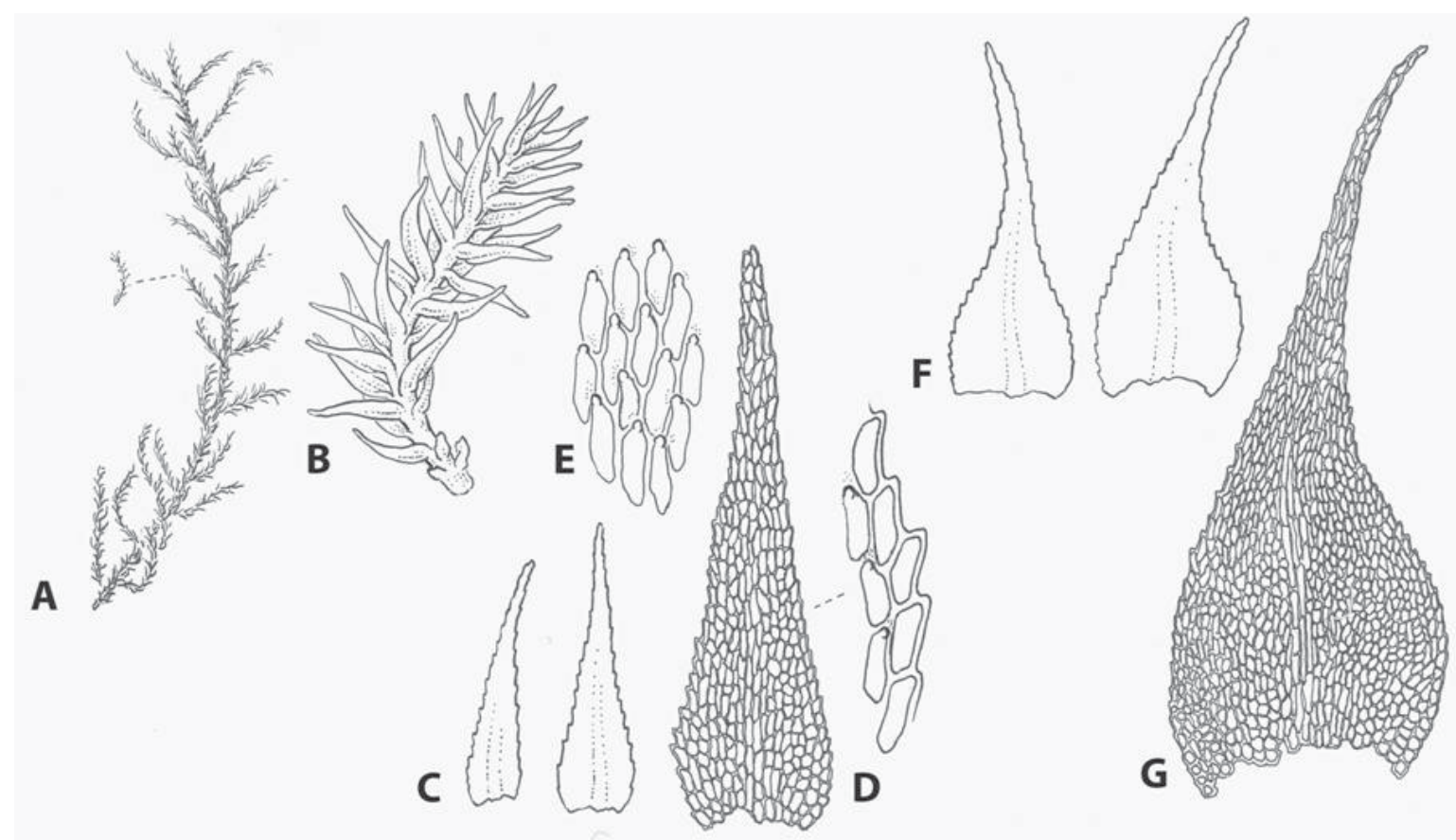

Fig. 1. Larrainia prorulosa. A. Habit, dry. B. Habit, moist. C. Branch leaves. D. Branch leaf areolation and marginal cells. E. Branch leaf cells showing prorulae. F. Stem leaves. G. Stem leaf areolation. Drawn from the holotype (Buck 60369, NY). See description for measurements.

lowing the manufacturer's instructions. The ITS region $($ ITS1 + 5.8S + ITS2) was amplified using the universal primers ITS1 and ITS4 (White et al., 1990). The amplicon was sequenced using the PCR primers and these reactions were performed using the ABI PRISM ${ }^{\circledR}$ BigDye $^{\mathrm{TM}}$ Terminators v. 1.1 Cycle Sequencing Kit (Applied Biosystems, Foster City, CA, U.S.A.) optimized for half- or quarter-size reactions. Sequencing products were purified using Sephadex G-50 (Amersham, Piscataway, NJ, U.S.A.) gel filters, and then separated by capillary electrophoresis using an ABI PRISM ${ }^{\circledR} 3100$ Genetic Analyzer. Nucleotide sequences were edited using Sequencher v. 3.1.1 (Gene Codes Corp., Ann Arbor, MI, U.S.A.). The ITS sequences (GenBank KJ736771) were added to a matrix of 54 selected Amblystegiaceae sequences available on GenBank. Sequences were aligned with MUSCLE v. 3.8.31 (Edgar, 2004) and all 664 sites were retained for the analyses. Phylogenetic relationships were inferred under the criterion of maximum likelihood (ML) and using Bayesian inference (BI) methods. The data were partitioned into ITS1, 5.8S and ITS2. Maximum likelihood analyses were carried out using RAxML v. 7.2.3 (Stamatakis, 2006). The topology with the highest likelihood score was chosen as the best tree. Statistical supports for branches were obtained via non-parametric bootstrapping with 100 pseudoreplicates. Bayesian inference was conducted using MrBayes v. 3.0b4 (Ronquist \& Huelsenbeck, 2003) assuming a GTR $+\mathrm{G}$ model of substitution for all partitions. Parameters for the different partitions were allowed to vary independently and branch lengths and topology were linked. Two runs each with four chains were performed with trees and parameters sampled every $1000^{\text {th }}$ generation. Burn-in and convergence were assessed using the likelihood of the runs plotted against generations using Tracer v. 1.5 (Rambaut \& Drummond, 2009). Posterior probabilities (PP) were estimated by sampling trees from the PP distribution. Trees were summarized after removing the burn-in samples. Finally, a 50\% majority-rule consensus tree was built in MrBayes.

\section{TAXONOMY}

Larrainia prorulosa W. R. Buck, gen. et sp. nov. Fig. 1

Plants small, bright green; stems creeping, to ca. 1.5 $\mathrm{cm}$ long, irregularly pinnately branched; in cross-section with small, thick-walled cells in 1-2 row(s) surrounding abruptly larger, thin-walled cells, central strand small; rhizoids in clusters on the undersides of stems, abaxial to leaf insertions, smooth; pseudoparaphyllia foliose, \pm triangular; stem and branch leaves somewhat differentiated. Stem leaves erect and \pm flexuose when dry, erectspreading to spreading when moist, ovate, $0.55-0.72 \times$ $0.20-0.28 \mathrm{~mm}, \pm$ abruptly long-acuminate, the acumen ca. 1/2 the leaf length; margins plane or narrowly and irregularly recurved at base, subentire toward apex, otherwise serrulate to serrate to supra-alar regions, with teeth spreading; costa single, ending in the acumen, subpercurrent to percurrent, \pm flexuose, not becoming more slender above and apex not projecting as a spine, but costal cells sometimes apically prorulose; laminal cells \pm hexagonal, $8.5-23 \times 5-6 \mu \mathrm{m}$, ca. $1.5-3(-4): 1$, sparsely prorulose at upper ends, especially above, becoming more elongate in the acumen and shorter juxtacostally toward the insertion; alar cells well developed, oblate, quadrate 


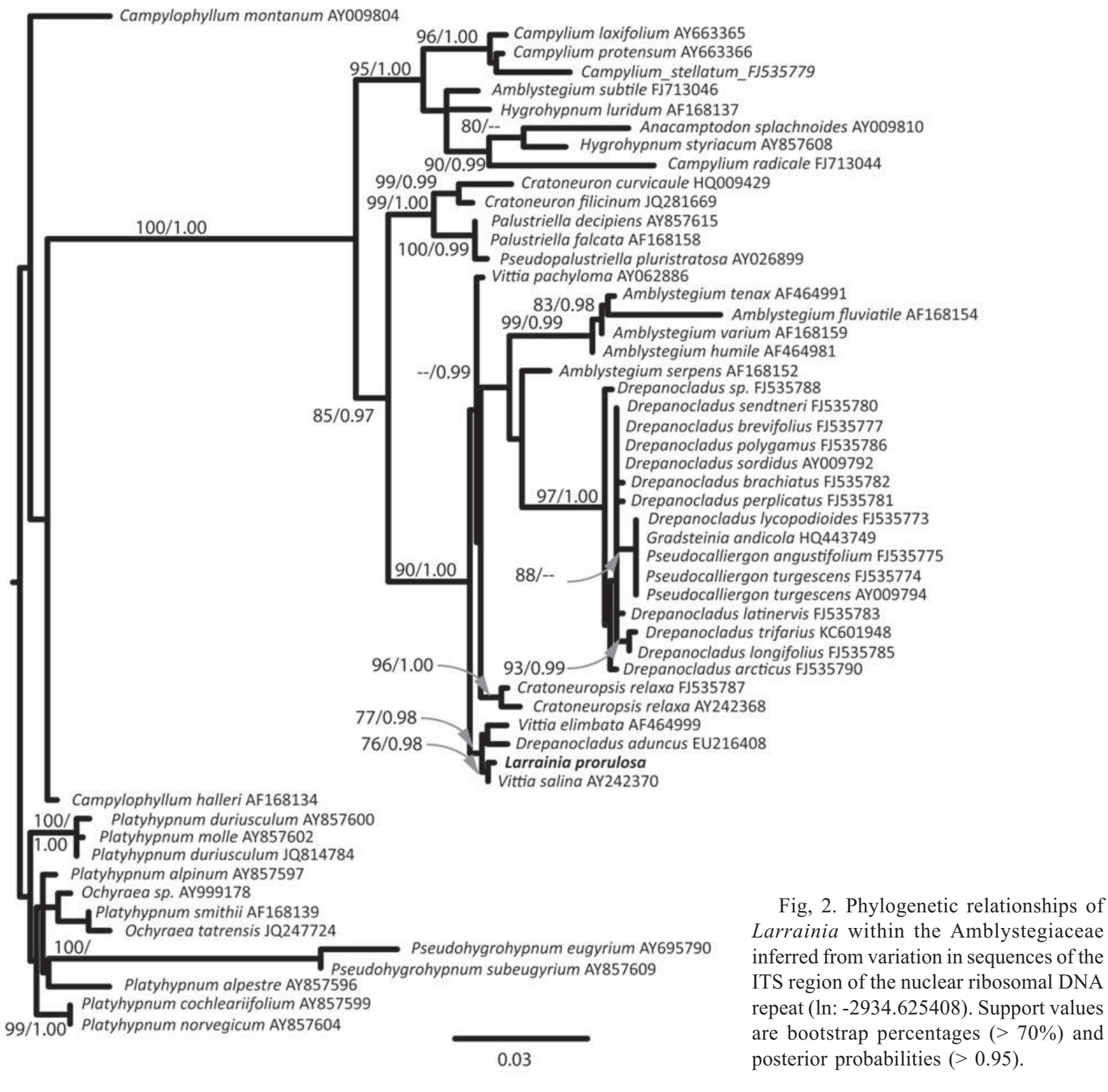

and short-rectangular, $0.8-3: 1$, extending up the margins by $4-8$ cells, not reaching the costa. Branch leaves erect-spreading and \pm flexuose when dry, spreading to wide-spreading when moist, lanceolate to narrowly ovate, $0.45-0.55 \times 0.11-0.14 \mathrm{~mm}, \pm$ gradually acuminate; margins plane, serrulate to serrate \pm throughout but more weakly so in the acumen; costa single, subpercurrent to percurrent, with cells often prorulose apically but apex not projecting as a spine; laminal cells \pm rounded shortrectangular, $11-17 \times 5.5-8 \mu \mathrm{m}$, ca. $1.5-3: 1$, mostly prorulose at upper ends; alar cells quadrate to short-rectangular, ca. $1-2: 1$, extending up the margins by $3-6$ cells, reaching the costa or separately from it by a single cells. Inflorescences and sporophytes unknown.

Type: CHILE. Prov. Antártica Chilena, Comuna Cabo de Hornos, Isla Grande de la Tierra del Fuego, Ventisquero Serka, NW of Bahía Yendegaia, 5448’02”S, $68^{\circ} 58^{\prime} 23$ 'W, ca. $80 \mathrm{~m}$; Nothofagus pumilio forest SE of glacier; on shaded calcareous rock ledge; 14 January 2013, W. R. Buck 60369 (holotype NY, holotype fragment CONN).

Additional specimen seen: CHILE. Prov. Antártica Chilena, Comuna Cabo de Hornos, Parque Nacional Alberto de Agostini, Isla Hoste, Península Dumas, Bahía Yekadahby, 5503'47'S, 68²5'19'W; moist Nothofagus betuloides-N. pumilio-Maytenus forest on E-facing slope with extensive rock outcrops; on humus; 15 January 2013, W. R. Buck 60404 (MO, NY).

Etymology: This new genus is named in honor of Chilean bryologist, Juan Bernardo Larraín Benoit (1979-), who is also a collaborator of the senior author on the bryoflora of the Cape Horn Archipelago. Juan has accompanied him on all the field work associated with this project and has been an ideal field companion since, with 
his youthful enthusiasm, he reaches altitudes I only look at. The specific epithet refers to the prorulose laminal cells, especially on the branch leaves.

\section{DiscUSSION}

Larrainia is characterized by very small plants with no leaves more than $0.8 \mathrm{~mm}$ long, slightly differentiated branch and stem leaves, a strong single costa, relatively short, prorulose laminal cells, and well-differentiated alar cells. The type collection was growing tightly appressed to calcareous rock on a shaded ledge but the other collection was on humus in a non-calcareous habitat.

Initially it was unclear as to the relationships of this small pleurocarp. Because of the small size, a number of moss families seemed possible. The two most probable families, for a temperate unicostate pleurocarp, are the Brachytheciaceae and Amblystegiaceae.

Larrainia differs from all other sympatric species of Brachytheciaceae by its small size, percurrent costa and prorulose laminal cells. It is probably most similar to Eurhynchiella acanthophylla (Mont.) M. Fleisch., newly found this far south (at the same locality as the paratype, on a shaded vertical rock wall, W. R. Buck 60426, NY) but that species has smooth, linear laminal cells, although it is of similar stature.

If this taxon had been described in the last century, it would probably have been placed in the genus Rhynchostegiella (Schimp.) Limpr. However, this genus has been restricted to a core of European-North African species (Aigoin et al., 2009). The three European species traditionally placed in Rhynchostegiella (e.g., Brotherus, 1925) but which molecularly were discordant with the others, were placed in three, newly described unispecific genera. Unfortunately, although morphology was discussed and a matrix made, the various genera, including Rhynchostegiella itself, were not morphologically characterized in a helpful manner. For example, during the study of this group in preparation of describing Larrainia, the senior author found that one of the most diagnostic characters for Rhynchostegiella s.str. is collenchymatous exothecial cells. None of the other segregate genera has this feature. However, it was not even mentioned by Aigoin et al. (2009).

Even more unfortunate, over half the species placed in Rhynchostegiella but which are extra-European were not even mentioned for the most part. Therefore, in trying to taxonomically position these mostly Asian species, all the material at NY was examined. The morphological diversity found among the Asian/Pacific species of Rhynchostegiella s.l. is staggering. Unquestionably more genera will need to be described. For example, $R$. smithii E.B. Bartram, from Fiji, is totally unlike the other species, with its ovate, obtuse leaves and setae only $1-2 \mathrm{~mm}$ long. There is also a group of species, including $R$. mindorensis (Broth.) Broth., R. opacifolia Dixon and $R$. papuensis E.B. Bartram, that are all similar with more or less acute, weakly decurrent leaves, margins serrate throughout, with a strong, single costa ending about 3/4 the leaf length and projecting apically as a spine, short laminal cells, and well-developed alar cells. Previously, Ignatov \& Huttunen (2002) resurrected a Rhynchostegiella segregate for a group of Asian species, Remyella Müll. Hal. In this genus, the leaves are ovate-lanceolate and serrulate to base, often with the leaf apex somewhat twisted. The costa ends at or below midleaf and the alar region is scarcely differentiated. The exothecial cells have thick vertical walls and thin horizontal walls, and the annulus is well developed.

Larrainia prorulosa is resolved, however, based on inferences from the nuclear ITS locus, within a core group of Amblystegiaceae composed primarily of Amblystegium and Drepanocladus (Fig. 2). Within this group Larrainia is most closely related to Vittia salina Hedenäs \& J.Muñoz and, with $V$. elimbata Hedenäs, Vanderpoorten \& Goffinet and a specimen identified as D. aduncus from Argentina (Biasuso et al. 105, S), and together they compose a weakly supported lineage. The identification of the latter was confirmed and its sequence, deviating from other $D$. aduncus samples, was already discussed by Hedenäs (2008). Vittia Ochyra is resolved as paraphyletic but considering the short branches, it is possible that $V$. pachyloma (Mont.) Ochyra, the type of Vittia, belongs to the same lineage with the other species of Vittia, the anomalous D. aduncus sample from Argentina, and Larrainia.

Phylogenetic resolution of aquatic or rheophilous species with bistratose lamina and terrestrial species with unistratose leaves in a single monophyletic group is not novel (see also Gradsteinia [Fig. 2] and Donrichardsia [Huttunen \& Ignatov, 2010]), and simply suggests that shifts in habitat trigger morphological transformations and that the latter should perhaps not be assigned taxonomic weight above the species rank. The polarity of these shifts is not well established and recent inference within Rhynchostegium suggests a perhaps counter-intuitive trend from aquatic to terrestrial habitats (Huttunen \& Ignatov, 2010). Although Larrainia is tentatively resolved as a sister-taxon to Vittia salina, it may be premature to accommodate the Cape Horn material within Vittia, given the lack of robustness of the relationships within Vittia, including the monophyly of the genus. Thus, we prefer to recognize these collections as a distinct genus on the basis of morphological differences until the phylogeny of the Amblystegiaceae and the affinities of all Vittia species are fully resolved.

Although the molecular data indicate a close relationship with Vittia, morphologically Larrainia seems most similar to Conardia H. Rob., as first suggested by Bruce Allen. Conardia was described to accommodate a single North Temperate species, C. compacta (Müll. Hal.) H. Rob., previously most often placed in Amblystegium, but also Brachythecium and Rhynchostegiella. Larrainia prorulosa differs from Conardia by its smaller size, 
smooth rhizoids, foliose pseudoparaphyllia, differentiated branch and stem leaves, considerably shorter and prorulose laminal cells, and lack of vegetative propagula on the abaxial surface of the costa, as well as its very different distribution. Conardia compacta is autoicous; inflorescences and sporophytes are unknown in Larrainia and thus it is probably dioicous. However, molecular data (Vanderpoorten et al., 2002) indicate that Conardia is not at all close to the Amblystegiaceae or Vittia.

\section{ACKNOWLEDGMENTS}

WRB thanks the U.S. National Science Foundation for grant DEB 0948380 (Collaborative Research on the Marchantiophyta, Anthocerophyta and Bryophyta of the Cape Horn Archipelago: Floristics and Implications for Conservation), which funded the fieldwork of this project. Bruce Allen first suggested a relationship to Conardia and we thank him for his discussion of the new taxon. The molecular component was supported by DEB1212505 (AToL: Assembling the Pleurocarp Tree of Life: Resolving the Rapid Radiation Using Genomics and Transcriptomics) to BG. We thank Nicholas Moskwa and Dr. Yang Liu (UCONN) for sequencing the type and analyzing the molecular data, respectively.

\section{LITERATURE CITED}

AIGOIN, D.A., S.M. HUTTUNEN, M.S. IGNATOV, G.M. DIRKSE \& A. VANDERPOORTEN. 2009. Rhynchostegiella (Brachytheciaceae): molecular re-circumscription of a convenient taxonomic repository.J. Bryol. 31: 213-221.

ANDREAS, B.K. 2013. A revision of Blindia (Seligeriaceae) from southern South America. - Bryologist 116: 263-280.

BROTHERUS, V.F. 1925. Brachytheciaceae. - In: A. Engler (ed.), Die natürlichen Pflanzenfamilien, ed. 2, 11: 349-380.

EDGAR, R. C. 2004. MUSCLE: Multiple sequence alignment with high accuracy and high throughput. - Nucl. Acids Res. 32: 1792-1797.

GARILLETI, R., V. MAZIMPAKA \& F. LARA. 2012. New Ulota spe- cies with multicellular spores from southern South America. - Bryologist 115: 585-600.

HEDENÄS, L. 2008. Molecular variation in Drepanocladus aduncus s.l. does not support recognition of more than one species in Europe.J. Bryol. 30: 108-120.

HOOKER, J.D. 1844-1860. The botany of the Antarctic voyage of H.M. Discovery ships Erebus and Terror in the years 1839-1843: under the command of Captain Sir James Clark Ross. - Reeve Brothers: London.

HUTTUNEN, S.M. \& M.S. IGNATOV. 2010. Evolution and taxonomy of aquatic species in the genus Rhynchostegium (Brachytheciaceae, Bryophyta). - Taxon 59: 791-808.

IGNATOV, M.S. \& S. HUTTUNEN. 2002 [2003]. Brachytheciaceae (Bryophyta) - a family of sibling genera. - Arctoa 11: 245-296.

RAMBAUT, A. \& A.J. DRUMMOND. 2009. Tracer v1.5. - Available from http://tree.bio.ed.ac.uk/software/tracer/.

RONQUIST, F. \& J.P. HUELSENBECK. 2003. MrBayes 3: Bayesian phylogenetic inference under mixed models. - Bioinformatics 19: 1572-1574.

ROZZI, R., J.J. ARMESTO, B. GOFFINET, W. BUCK, F. MASSARDO, J. SILANDER, M.T.K. ARROYO, S. RUSSELL, C.B. ANDERSON, L.A. CAVIERES \& J.B. CALLICOTT. 2008. Changing lenses to assess biodiversity: patterns of species richness in sub-Antarctic plants and implications for global conservation. - Frontiers Ecol. Environm. 6(3): 131-137.

ROZZI, R., F. MASSARDO \& C. ANDERSON (eds.). 2004. Reserva de Biosfera Cabo de Hornos: una propuesta de conservación y turismo para el desarrollo sustentable en el extremo austral de América. - Ediciones de la Universidad de Magallanes: Punta Arenas, Chile.

STAMATAKIS, A. 2006. RAxML-VI-HPC: maximum likelihood-based phylogenetic analyses with thousands of taxa and mixed models. - Bioinformatics 22: 2688-2690

VANDERPOORTEN, A., L. HEDENÄS, C.J. COX \& A.J. SHAW. 2002. Phylogeny and morphological evolution of the Amblystegiaceae (Bryopsida). - Molec. Phylogenet. Evol. 23: 1-21.

WHITE, T.J., T. BRUNS, S. LEE \& J.W. TAYLOR. 1990. Amplification and direct sequencing of fungal ribosomal RNA genes for phylogenetics. - In: M.A. Innis, D.H. Gelfand, J.J. Sninsky \& T.J. White (eds.), PCR Protocols: A Guide to Methods and Applications. Academic Press Inc., New York: 315-322. 